\title{
The Nature and Problems of Tax Administration in the Russian Federation
}

\section{Elena Konvisarova}

Irina Samsonova

Olga Vorozhbit

\author{
Vladivostok State University of Economics and Service, Russia, Vladivostok, Gogol st., 41 \\ Email: elena.konvisarova@vvsu.ru, irina.samsonova@vvsu.ru, Olga.Vorozhbit@vvsu.ru
}

\author{
Doi:10.5901/mjss.2015.v6n5s3p78
}

\begin{abstract}
Financial activity of the state on getting taxes and improvement of the investment climate will be effective only at development of an optimal mechanism of tax administration $n$. It involves, on the one hand, the possibility of replenishment of the budget and, on the other, lack of prerequisites for tax evasion. However, currently existing methods of tax administration have drawbacks (in the rules, the timing of tax audits, the list of available documents, evidential base and other) and are a deterrent to the budget replenishment. The mechanism of tax administration, which could reduce the costs of tax legislation both for tax authorities and taxpayers on the principles of mutual responsibility, is necessary. Problems of practical work of tax administration according to the authors lie in the groundless theory of matter. To solve these problems, the authors investigated the economic and legal essence of the concept of "tax administration" in the absence of legislative regulation and multiplicity of approaches by different authors. The study of diametrically opposite and similar approaches has allowed to identify tax administration as the institution responsible for the raising of taxes and fees, as a component of the mechanism of management of the tax system in the framework of tax policy; its purpose is to provide the budgetary system of tax revenue under the optimal combination of specific methods; its object - monetary relations between the state and taxpayers regarding the mobilization of tax revenues to the budget system; its subject - fiscal relations, generating cash flows in the respective budgets at the expense of tax payments.
\end{abstract}

Keywords: tax administration, taxation system, mechanism.

\section{Introduction}

The taxation system is the basis of the mechanism of state regulation of the economy through financial leverages. The effective functioning of the entire economy of the country depends on a well-established taxation system. Therefore, Russia's taxation system needs to reflect the realities and needs of the current state of the economy taking into account its national characteristics and with the involvement of international experience.

The state should have a reliable mechanism for tax collection to obtain the necessary funds in the budget. One of the main components in this mechanism is the tax administration. Financial activity of the state on getting of taxes and improvement of the investment climate will be effective only at development of an optimal mechanism of tax administration, which involves, on the one hand, the possibility of replenishment of the budget and, on the other lack of prerequisites for tax evasion.

However, currently existing methods of tax administration are the deterrent of budget replenishment. Objections of participants of the economic relations are mainly provoked by functions of the control exercised by the tax authorities: the rules for the tax audits and the timing of the audit; a list of documents that the tax authorities may request at the desktop and counter checks. The low quality of inspections, lack of evidence on revealed tax violations at the recovery of tax sanctions, increasing of the number of one-day firms, etc. - all these point to poor administration mechanism. It is necessary that the mechanism of tax administration does not simply reduce the costs of tax compliance for both tax authorities and taxpayers, but also forms the understanding of the inevitability of discovery of the violation and sanction in the budget the full amount of taxes due to pay. (Paizulaev, p.16).

\section{Methodology}

To solve these problems, it is necessary to consider the economic and legal essence of the concept of "tax 
administration" in the absence of legislative regulation and multiplicity of approaches of different authors.

"Tax administration" as a phenomenon and as a concept arose with the "arrival" of a market economy. In the socialist economy there was another (non-tax) system of formation of the state budget.

In market conditions the first tax administration was formulated by Ospanov (2012, p. 289) as "the implementation of the tax administration within its jurisdiction functions and powers established by government and tax legislation. The main component of tax administration is the tax management system. It includes a complex of measures: optimization of tax structures; improvement of the mechanism of taxation, tax accounting and reporting; control over correctness of calculation, timeliness and completeness of payment of taxes; compliance of, established by the tax legislation, rights and obligations of tax authorities and taxpayers; distribution of tax revenues between budgets of different levels; collection and analysis of results; preparation of suggestions to improve their effectiveness; harmonization of tax relations of all participants of the process of taxation."

Krasnitsky (2010, p. 72-75) considers tax administration as a management system of tax relations, which main task is to develop new forms adequate to the state of the productive forces, and also forecasting of tax revenues in the medium term on the basis of forecasts revenue growth of the economy; development of new concepts of taxation; preparation of tax studies of the implementation of protectionist policies of foreign economic activity

The main methods of tax administration are tax planning, tax management and tax control. Each of these methods has its forms of implementation, aimed at solving specific problems. The purpose of tax administration, therefore, is the provision of planned tax revenues to the budget system in terms of the optimal combination of methods of tax regulation and tax control" (Vorojbit and Samsonova,2013).

At first, tax administration were treated as a set of methods, techniques and tools of information provision by which the governing bodies give to the functioning of the tax mechanism, specified by the law, direction and coordinate tax action due to significant changes in the economy and politics, and then, "in the broad understanding the tax administration is a system of government fiscal relations in action..." This concept is revealed in two sides (Vinnickiy, 2012, p. 10-11).

First, it is a system of administration (legislative and administrative tax authorities). The scope of their procedural duties includes ensuring the passage of the tax concepts for the next planning period: consideration and discussion, the legislative approval. In addition, they must make reports on the realization of the tax budget, subject them to comprehensive analysis.

Secondly, it is set of rules and regulations regulating tax actions and specific tax technique, and also determining measures of responsibility for violation of tax legislation.

\section{Results}

Based on the foregoing, the authors conclude that tax administration is elaboration of the legal basis of taxation on the basis of historical experience, modern achievements of economic science and practice, as well as providing conditions for the functioning of a particular taxation mechanism and its elements (planning, regulation, control), and the establishment of accounting and analytical, reporting rules, documents, and etc.

Among the problems facing tax administration, the authors indicate:

- the development of new concepts of taxation, promoting business development without compromising the government's social programes;

- preparation of tax justifications to ensure protectionist policy in the system of foreign economic activity.

Thus, it appears that in the content of the tax administration are budgeted all aspects of tax relations, in fact, including the development of government tax policy.

Very close to this position are some other scholars, for example, Porshnev (2015,p. 62-63) defining the relationship of "state tax management" with the actual practices of the various state decisions in the tax area, in particular, the implementation of tax reforms aimed at accelerating the accumulation of capital and the stimulation of business activity.

This approach to tax administration seemed groundless broad. Tax policy is a category which reflects general trends in the development of tax relations, including in relation to a particular stage of economic development of the country. And tax administration is mostly connected with the practical activities of tax authorities. The successful implementation of the state tax policy in practice requires an effective system of organization and management activities, i.e., management of taxes, or tax relations or tax system.

Taxes as a theoretical abstraction of tax relations in the organizational plan are seemed to the tax system in a comprehensive understanding, respectively, the management of tax relations (taxes) are also rightly regarded as the management of the tax system, but represented with all its elements. Accordingly, identifying tax administration as the 
management of tax relations, the concepts of tax administration and management of the taxation system are practically identified as a complex concept.

"Taxation system" is also an ambiguous concept in the economic literature. (Maiburov, 2011, p. 68) for example, considers it to be based on certain principles of holistic unity of interrelated and interdependent elements .

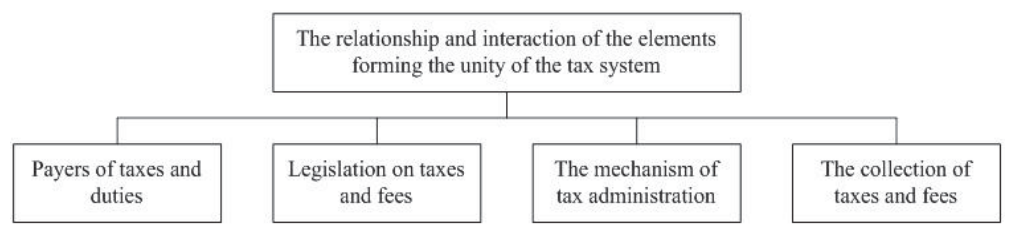

Figure 1 - Taxation system elements

Management of the taxation system as a complex concept can be seen as the activity of the state (legislative, executive, administrative activities of authorized bodies) on management of each element included in the definition of the taxation system.

Considering the tax system as a complex concept, we cannot agree with the identification of the concepts of "tax administration" and "management of the tax system". The first is narrower in content than the second.

Recognizing that tax administration is part of management of the tax system whereby the tax administration is an element of the tax system, by assuming that it to some extent contradicts itself, the following definition is giving: "Tax administration is the process of managing of production tax implemented by taxes and other authorities (tax authorities) with certain powers in respect of taxpayers and payers of fees" (Dadashev and Lobanov, 2012, p. 38-50).

Tax administration is presented as the activities of the competent authorities, namely the Federal tax service of Russia and its territorial bodies, partly the Ministry of Finance, aimed at ensuring control of observance of the tax legislation by all participants of tax relations. Thus the tax administration still includes the current and subsequent monitoring of the development of the taxation system, with the aim of predicting and assessing the impact of implemented or proposed changes in legislation to ensure the effectiveness of control measures. Accordingly, in the contents of tax administration should be included preparation of suggestions on improving tax legislation in respect of the forms and methods of tax relations, but with emphasis on the improvement of tax control (administration) for the calculation of the tax payments.

The activities of state authorities aimed at implementing mainly the regulatory impact of taxes, is the management of the taxation system in part undertaken by other bodies and authorities (the Ministry of Finance, Ministry of economic development of Russia and other interested and authorized administrative agencies).

Thus, the management of tax relations, management of the taxation system as a combination of three elements is a broader notion, and tax administration is its part, representing the activities of the competent (specialized) state administration bodies.

At the same time, it is believed that in tax relations cannot be a full concept of "control" in terms of the relationship of the tax authority, on the one hand, and legal and physical persons on the other. Tax and custom authorities are not empowered to manage taxpayers, tax agents and other persons under obligation. Some researchers refute this view, believing that "the authorities of the state are vested with the authority to fulfill directives, power decisions in respect of the taxpayer upon the occurrence of appropriate conditions they have the right to take disciplinary action. In fact, it suggests that the administration is in existence".

The authors highlighted the terms that refer to "tax administration":

- state tax administration (of state tax management) and corporate tax management (corporate tax management);

- state tax administration (the work of tax authorities) and tax management (activities of taxpayers);

- state and banking tax management and tax control.

The analysis of the essence of management activities at different levels of government administration and in organizations from the point of view of the theory of management, it seems more fair to allocate tax administration as the management activities of the state represented by authorized bodies of executive power, while tax management should be considered as an activity of organizations on management of tax payments.

Tax management may be realized only within a particular organization and may spread on tax payments, calculated in the legally prescribed manner. The activity of state bodies of legislative and executive powers in tax matters 
is more versatile than "state tax administration". It includes the development of state tax policy, legislative support of taxation, the creation of an effective taxation system, ensuring of an effective tax control.

The concept of "tax administration" is actually in the identification of tax administration with taxation law. Thus, Koren and Tatuiko (2014, p. 134-137) believe that "tax administration is one of the legal institutions of taxation law». And this is can be explained in connection with the legal regulation of the relationship between tax authorities and taxpayers, the mandatory nature of the tax and legal liability of the taxpayer. At the same time, the essence of tax administration also includes "lawless" elements:

- development and application of methods for determining taxpayers subjected to tax inspections,

- methods of conducting field audits on groups of taxpayers and revealing the facts of understating of tax base, for example, as a result of a wrong understanding of the economic substance of the transaction, etc.,

- monitoring, evaluation and development of suggestions for amending or supplementing the legislation on taxes and levies in legal groundwork (procedural, processual) to ensure relations between all participants of tax relations.

Tax administration, according to Goncharenko(2010, p. 17), is in the identification of this concept with the tax control, also due to the translation of a foreign term "tax administration" as tax control by the competent authorities.

Actually the content of tax administration is broader than the tax control, it is the function of tax administration along with the other functions of management: planning, accounting and control.

The differences between the tax administration and tax control in detail and convincingly are presented by Aronov and Kashin (2011, p. 477) Differences between the tax administration and tax control are following:

1. in subject-object composition;

2. in goal setting;

3. In functional characterization;

4. In the principles of implementation;

5. in methods of implementation.

Table 1 - Distinguishing criteria of tax administration and tax control

\begin{tabular}{|c|c|c|}
\hline Criteria & Tax administration & Tax control \\
\hline Essential characteristic & $\begin{array}{l}\text { Tax administration is a control system of tax } \\
\text { relations }\end{array}$ & $\begin{array}{l}\text { Tax control is an element of financial control and of tax } \\
\text { mechanism }\end{array}$ \\
\hline ubject & $\begin{array}{l}\text { Tax relations } \\
\text { Planning }\end{array}$ & $\begin{array}{l}\text { The activity of the entity as the taxpayer } \\
\text { Fiscal }\end{array}$ \\
\hline unctions & $\begin{array}{l}\text { Accounting and control } \\
\text { Regulation }\end{array}$ & $\begin{array}{l}\text { Control } \\
\text { Regulatory }\end{array}$ \\
\hline Methods & $\begin{array}{l}\text { The set of methods of interaction between tax } \\
\text { authorities and taxpayers, as well as a set of } \\
\text { methods for implementation of control measures }\end{array}$ & $\begin{array}{l}\text { Only set of methods of implementation of control } \\
\text { measures }\end{array}$ \\
\hline Aim & $\begin{array}{l}\text { Optimal organization of tax relations by authorized } \\
\text { bodies of executive power for maximum realization } \\
\text { of the fiscal aspects of taxes and fees } \\
\text { Promotion of the prestige of the tax service and the } \\
\text { tax culture of taxpayers } \\
\text { Improvement of cooperation with taxpayers while } \\
\text { making tax relations } \\
\text { Tax collection improving }\end{array}$ & $\begin{array}{l}\text { Ensuring of completeness of tax revenue to the budget } \\
\text { through control measures, including obstruction of tax } \\
\text { evasion } \\
\text { Ensuring completeness and timeliness of tax } \\
\text { obligations by taxpayers } \\
\text { Tax legislation compliance and prevention of its } \\
\text { breaches } \\
\text { Control over the correctness of conducting accounting } \\
\text { and tax accounting and preparation of accounting and } \\
\text { tax reporting }\end{array}$ \\
\hline Goals & $\begin{array}{l}\text { Resistance of tax evasion and use of tax schemes } \\
\text { Prediction of the development of tax relations }\end{array}$ & $\begin{array}{l}\text { The supervision of banks in the fulfillment of their } \\
\text { interaction with taxpayers }\end{array}$ \\
\hline
\end{tabular}

\section{Conclusion}

Thus, considering different points of view on the term "tax administration", different ways to group them, it should be noted that each view is rational, and the idea, around which the logic of evidence is built confirming the correctness of the author. Each new researcher agrees with the arguments and refuses others, formulating his own idea of the term, event, phenomenon. 
In respect of tax administration there is even the view that "there is no need to search for a precise definition of the considered term, it is only the expression of a descriptive nature that needs no definition... acceptance is shifting on that one of the participants of tax relations is administrative and the other is administering... from the point of view of logic of public administration, there is no problem..." (Lelikova and Konvisarova, 2015).

At the same time, a clear understanding of the phenomenon, its nature, content and relationships allows to use it effectively in the development of suggestions on improving the mechanism of its functioning to stabilize the financial system of the state.

Therefore, the detailed analysis different considered definitions led to the conclusion that the truth lies somewhere between the two extremes of identifying tax administration: tax control and tax management system.

Tax administration is not just an economic category, but the Institute, connected with the tax policy of the state, system management, tax authorities, tax control. In accordance with the institutional approach the tax administration includes two aspects: institutional norms and authorized bodies (Kuklina, 2013; Koren and Zviaginceva, 2015).

Tax administration should be considered as the institution responsible for the mobilazation of taxes and fees and as a part of procedures for the administration of the tax system in the framework of tax policy, expressing the legal relations between the state, municipal entities and obligated persons.

The purpose of tax administration - ensuring budgetary system by tax revenue under the optimal combination of methods of tax planning, accounting, control and regulation based on the principles of taxation.

The object of tax administration is money relations between the state, on the one hand, and legal and physical persons, on the other hand, regarding the mobilization of tax revenues to the budget system.

The subject of tax administration is tax relations, ensuring cash receipts, including taxes, at the federal, regional and municipal budgets (Koren and Tatuiko, 2014 \& Samsonova, 2010).

Analysis of different perspectives on the functions of tax administration revealed a significant drawback inherent in members of a "managerial" position, as well as in additional supporters of the idea of grouping not set of consistent procedures for the management, nor the list of grouped tasks do not describe the mechanism of tax administration.

The mechanism of tax administration can be defined as a set of organizational forms, types, methods and techniques of the activity of authorized bodies - administrators for the management of tax relations with the aim of achieving stable tax revenues to the budget system while maintaining the balance of public and private interests.

Describing the tax mechanism as organizational and management system for the implementation of tax administration the following should be considered:

- tax mechanism is an integral element of the overall system state management of the economy and occupies a special place due to the nature of implemented through objective distribution relations;

- tax mechanism contributes to the realization of the direct and inverse relationship between the economy (the basis) and the state (superstructure),- therefore, it is not only determined by the tax relations, but also has a reverse effect on them;

- development and improvement of the tax mechanism is due to the state of the economy, and the necessity of solving specific problems of management, which determines the mobility of its elements, their restructuring following the cyclical nature of reproductive processes;

- the internal structure of the tax mechanism is characterized by systemic integrity of relatively independent structural and functional units and elements.

The mechanism of tax administration includes the principles, functions, methods, tools, levers and structural modules.

Tax administration is in a subordinate position to the entire tax system. The peculiarity of the institute of tax administration is the effect of the method of administrative guidance: the subjects of the tax administration are carried out by tax relations on the basis of requirements of the legislation, and not by choice. At the same time, the possibility of choice is in the specific procedures and criteria for assessing the actions or omissions of participants of relations in the sphere of taxes established by the Tax code of the Russian Federation. Therefore, when considering the nature and institutional structure of a mechanism of tax administration, it is necessary to include a strict system of legal regulation.

\section{References}

Aronov, A.V. \& Kashin V.A. (2011). Taxes and taxation. Moscow.

Vorojbit, O.Y. \& Samsonova I.A. (2013).Conceptual Model of Implementation of Regulatory Impact Assessment at the Regional Level. Middle East Journal of Scientific Research, http://www.idosi.org/mejsr/mejsr14(8)13/14.pdfSN 1990-9233 @ IDOSI Publications. Vinnickiy, D.V. (2012) Some actual problems of tax administration. The laws of Russia: experience, analysis, practice, 3, 10-11. 
Goncharemko, L.I. (2010) To the question of the conceptual framework of tax administration, Taxes and taxation, 2, 24-26.

Dadashev, A.Z. \& Lobanov A.V. (2012) Tax administration in the Russian Federation. Moscow.

Krasnickiy, V.A. (2010). Organization of tax administration (Dissertation of PhD) Institute of Economics, Law and Humanities. Krasnodar. The Russian Federation.

Kuklina, T.V. (2013) Theoretical basis and classification of tax administration. Bulletin of the Tomsk state University. Economy, 14 (24), 136-142.

Koren, A.V. \& Zviaginceva A.S. (2015) The organization of the control of tax authorities: the methods and ways of its improvement, International journal of applied and fundamental research, 3 (1), 59-62.

Koren, A.V. \& Tatuiko A.V. (2014) Regional tax policy as a tool for creating a favourable investment climate in the far East, Global scientific potential, 11 (44). 134-137.

Lelikova, N.A. \& Konvisarova E.V. (2015). Assessment of trends in the use of special tax regimes in Russia. Modern problems of science and education, 1,433 .

Maiburov, I.A. (2011). Taxes and taxation. Moscow.

Ospanov, M.T. (2012). Tax reform and harmonization of tax relations. Saint-Petersburg.

Paizulaev, I.R. (2012) The formation and development of tax administration in the Russian Federation (theory and practice) (Dissertation of $\mathrm{PhD}$ ) Over-Russian correspondence financial and economic Institute. Moscow. Russian Federation.

Porshneva, A.G. (2013). Tax management. Moscow. UNITY-DANA.

Samsonova, I.A. (2010). Tax literacy of people as a way to protect financial interests. The territory of new opportunities. Bulletin of the Vladivostok state University of Economics and Service,5,54-55. 